\title{
ALAT UKUR TINGGI MUKA AIR BERBASIS WEB
}

\author{
Syarif Hidayat ${ }^{1}$, Mushlihudin ${ }^{2}$ \\ ${ }_{1}^{1}$ Program Studi Teknik Elektro, Fakultas Teknologi Industri, Universitas Ahmad Dahlan \\ 2Program Studi Teknik Informatika, Fakultas Teknologi Industri, Universitas Ahmad Dahlan \\ Kampus III UAD, JI. Prof. Dr. Soepomo, Janturan, Yogyakarta 55161 \\ email: hidayat81@ymail.com, mdin@ee.uad.ac.id
}

\begin{abstract}
Indonesia is a country that has the high rainfall, so many dam was built in this country. Dams can be used as a backup water supply, irrigation and electricity generation. Dams can also be used as a prevention of floods, because dams can be utilized as rainwater. However, the water flow and the high amount of rainfall that can cause flooding and can collapse the dam. So that, we need a tool that can measure the amount of water level in the dam. The design water level measuring devices includes two parts. First, the hardware design which includes using the circuit microcontroller of the Arduino Nano 328 and the ultrasonic sensor to read the water level. The second is the design of software as a media viewer reading sensor. So that, this system can be implemented in the dam desired. The results of this study provide information on the water level simulated by the water reservoir, the water level is read by an ultrasonic sensor. When water is reduced or increased will be read by the ultrasonic sensor, and then the data is displayed on prangkat $p c$ and smartphone in the form of web. Data numeric water level is displayed on the web change - change for the ultrasonic sensor to detect objects that are not setatis with a difference of 0.01 from the measuring instrument readings comparison.
\end{abstract}

Keywords: water level; dam; arduino; ultrasonic sensor; web

\begin{abstract}
Abstrak
Indonesia merupakan negara yang memiliki curah hujan yang cukup tinggi, oleh karena itu banyak dibangun bendungan. Bendungan dapat dimanfaatkan sebagai sumber air cadangan, irigasi dan sebagai pembangkit listrik. Bendungan juga dapat dimanfaatkan sebagai pencegah bencana banjir, karena bendungan dapat di manfaatkan sebagai penampung air hujan. Akan tetapi jika debit dan jumlah curah hujan teralalu tinggi maka akan menimbulkan bencana banjir dan kemungkinan bendungan akan rawan jebol. Karena itu diperlukan sebuah alat yang dapat mengukur jumlah ketinggian air pada sebuah bendungan. Perancangan alat ukur tinggi muka air meliputi 2 bagian. Pertama, perancangan perangkat keras yang meliputi penggunaan rangkaian arduino nano 328 sebagai pengendali sensor untuk membaca tinggi permukaan air. Kedua adalah perancangan perangkat lunak sebagai media penampil hasil pembacaan yang dilakukan sensor yang digunakan. Sehingga system ini dapat diimplementasikan di bendungan yang dikehendaki. Hasil dari penelitian ini memberikan informasi tinggi permukaan air yang disimulasikan oleh bak penampung air, ketinggian air tersebut dibaca oleh sensor ultrasonik. Saat air dikurangi atau ditambah akan terbaca oleh sensor ultrasonik, kemudian data ditampilkan pada prangkat pc dan smartphone dalam bentuk web.Data berupa angka ketinggian muka air yang tertampil pada web berubah - rubah karena sensor ultrasonik mendeteksi objek yang tidak setatis dengan selisih pembacaan 0,01 dari alat ukur pembanding.
\end{abstract}

Kata Kunci: tinggi air; bendungan; arduino; sensor ultrasonic; web 
1.

\section{Pendahulan}

Secara letak geografis Indonesia merupakan salah satu negara yang memiliki 2 musim. Salah satunya adalah musim hujan. Tingkat curah hujan yang tinggi selalu terjadi hampir di setiap daerah sehingga di bangun beberapa bendungan. Bendungan tersebut dipergunakan untuk mengatasi besarnya debit air yang berpotensi menciptakan banjir di suatu daerah. Peningkatan jumlah debit air yang diakibatkan tingginya curah hujan akan dapat mengakibatkan bencana banjir dan bendungan akan beresiko mengalami kerusakan. Oleh karena itu diperlukan sebuah alat yang dapat mengukur jumlah ketinggian air pada sebuah bendungan.

Selama ini petugas penjaga bendungan melakukan pengukuran ke tinggian air dibendungan secara manual yakni dengan cara melihat alat ukur elips yang berada disamping bendungan hal ini kurang efisien karena jika musim hujan datang maka penjaga bendungan harus tetap mengecek tinggi air dibendungan hal ini dapat membahayakan keselamatan penjaga bendungan dihawatirkan penjaga bendungan tergelincir dan jatuh ke dalam bendungan.

Maka diperlukan alat ukur yang dapat mengukur muka air di bendungan tanpa harus berada disekitar bendungan.Perkembangan teknologi yang semakin peseta memungkinkan untuk membuat alat yang dapat memberikan informasi secara riltime tanpa harus berada disekitar bendungan.Alat ukur yang dibuat menggunakan sensor ultrasonic untuk mengukur tinggi permukaan air dan hasil pembacaan akan ditampilkan pada web. Data dari web dapat di akses oleh perangkat smartphone karena smartphone mudah dibawa dan diakses dimanapun dan kapanpun jadi petugas bendungan hanya membuka web dan melihat tinggi benduangan dari jarak jauh .Dengan adanya alat ini petugas penjaga bendungan dapat melihat tinggi permukaan air tanpa harus mendatangi bendungan untuk memantau ketinggian air pada bendungan.

Tabel 1. penelitian terdahulu

\begin{tabular}{rlll}
\hline No & Peneliti & Sensor yang Digunakan & Keluaran dari Sistem \\
\hline 1 & Widjaja dkk (2012) & Ultrasonik Ping & SMS, Modul GSM \\
\hline 2 & $\begin{array}{l}\text { Didi Rachmadi } \\
\text { (2014) }\end{array}$ & Ultrasonik Ping & SMS, Modul GSM Shield \\
\hline 3 & Fadlum (2011) & Ultrasonik & LCD \\
\hline 4 & $\begin{array}{l}\text { Syarif Hidayat } \\
\text { (Tugas Akhir 2016) }\end{array}$ & Ultrasonik Ping & Web \\
\hline
\end{tabular}

Alat tinggi muka air berbasis web menampilkan data dalam bentuk web dan dapat menampilkan data dalam kondisi realtime, kondisi pada saat pengukuran dengan waktu delay 1 detik dan dapat di akses di berbagai tempat menggunakan smartphone.

\section{Metode Penelitian}

\subsection{Perancangan Perangkat Keras}

Perancangan perangkat keras terdiri dari arduino nano 328 yang berfungsi sebagai pengendali sensor dan pengolahan data pada sensor ultrasonik. Sedangkan web berfungsi sebagai penampil data. Perancangan perangkat keras dapat dilihat pada Gambar 1.

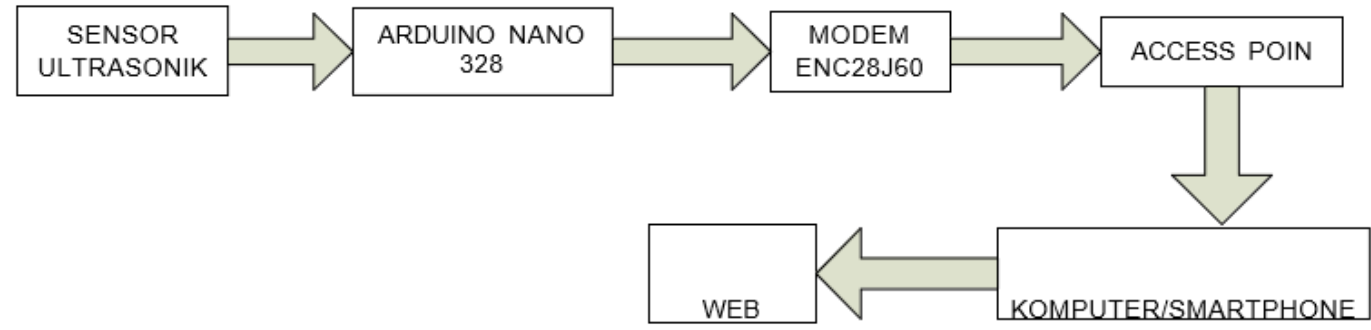

Gambar 1. Blok diagram 


\subsection{Perancangan Perangkat Keras}

Diagram alir prangkat lunak dari alat tinggi muka air berbasis web dengan cara kerja alat mengalami proses inisilalisasi atau proses memasukan eternet,variabel jarak, durasi ultrasonik, IP, MAC, komunikasi serial pin I/O echo dan triger selanjutnya alat membaca data dari sensor berupa data gelombang ultrasonik jika eternet terdeteksi maka maskan IP yang di gunakan untuk menampilkan data dari sensor jika tidak terkoneksi maka tampilan pada prangkat penampil gagal tersambung ditunjukkan Gambar 2.

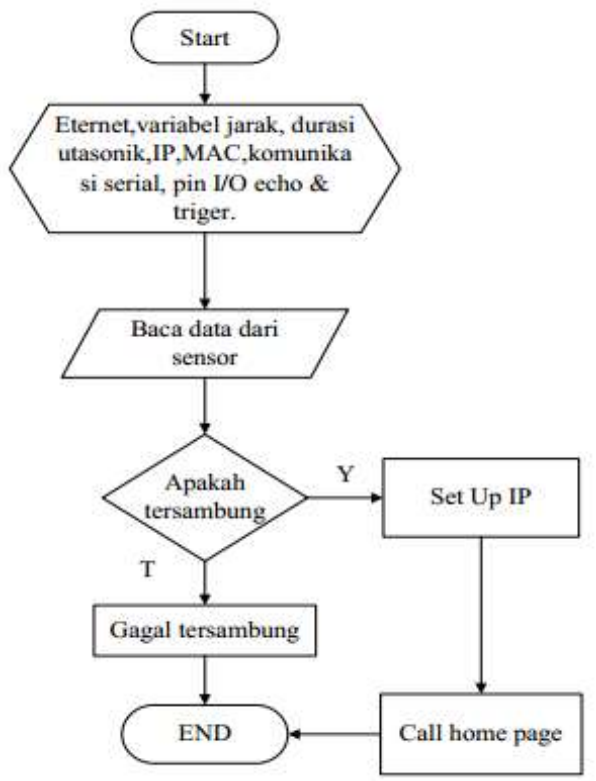

Gambar 2. Flowchart

\section{Hasil Dan Pembahasan} berikut :

Hasil dan pembahasan dari perancangan yang telah dibuat dapat di uraikan dengan langkah

\subsection{Pengujian Sensor Ultrasonik}

Pengujian sensor ping ultrasonic dilakukan dengan metode pengujian jarak dengan menggunakan penggaris sebagai media ukur, kecocokan antara jarak dari meteran dan hasil yang di tampilkan pada web.

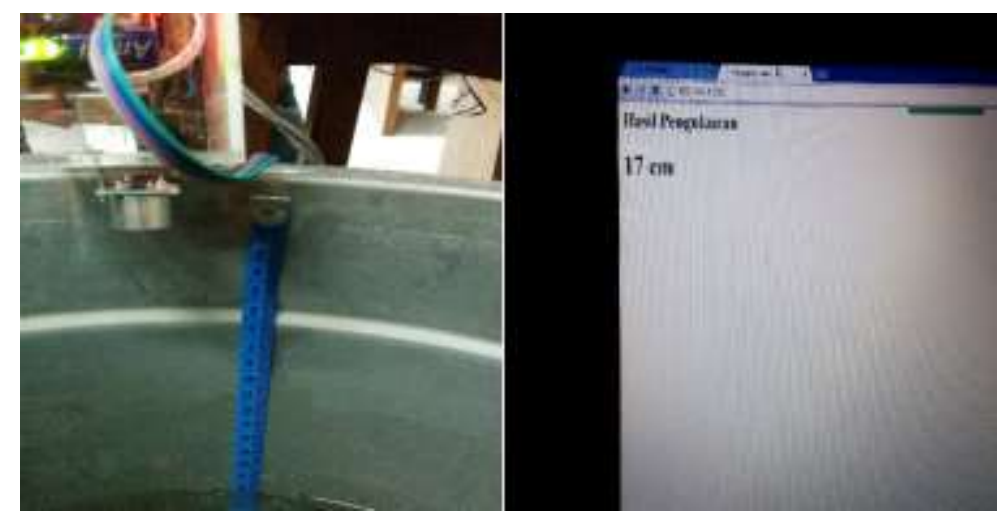

(a)

(b) 
Gambar 3. (a) Mendeteksi tinggi muka air (b) tampilan pada website

Gambar 3 (a) menunjukkan cara pengujian sensor ping ultrasonic, terlihat pada gambar sensor ping ultrasonic mendeteksi permukaan air dalam ember, di dalam ember terdapat alat ukur berupa meteran. Kemudian pada gambar (b) hasil pembacaan dari sensor ping ultrasonik akan di tampilkan pada web.

\subsection{Pengujian web}

Dilakukan dengan cara menjauhkan prangkat penerima dari tpling dan hadwer seberapa jauh web dapat menerima data dari alat tinggi muka air berbasis web dan pengujian web ditunjukkan Gambar 4

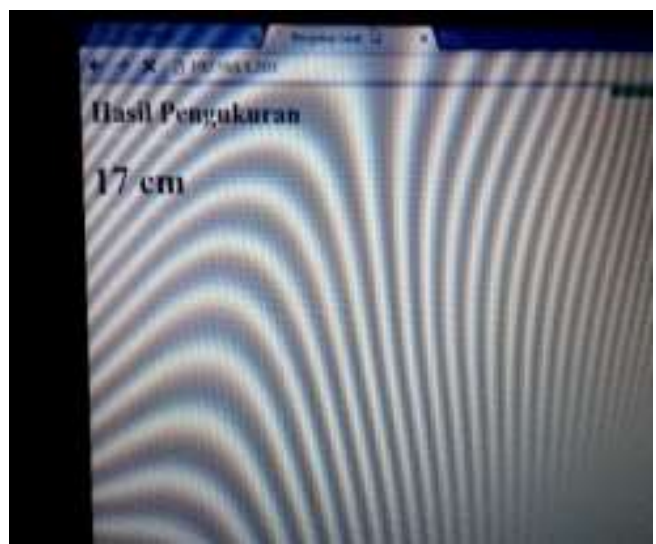

Gambar 4. Tampilan pada website

\section{Proses Pengujian Alat Keseluruhan}

Proses pengujian keseluruhan dilakukan dengan cara mengisi air pada ember, air yang ada di ember dideteksi permukaannya oleh sensor ping ultrasonik, kemudian hasil dari pembacaan sensor ping ultrasonic ini akan di tampilkan pada web ditunjukkan Gambar 5.

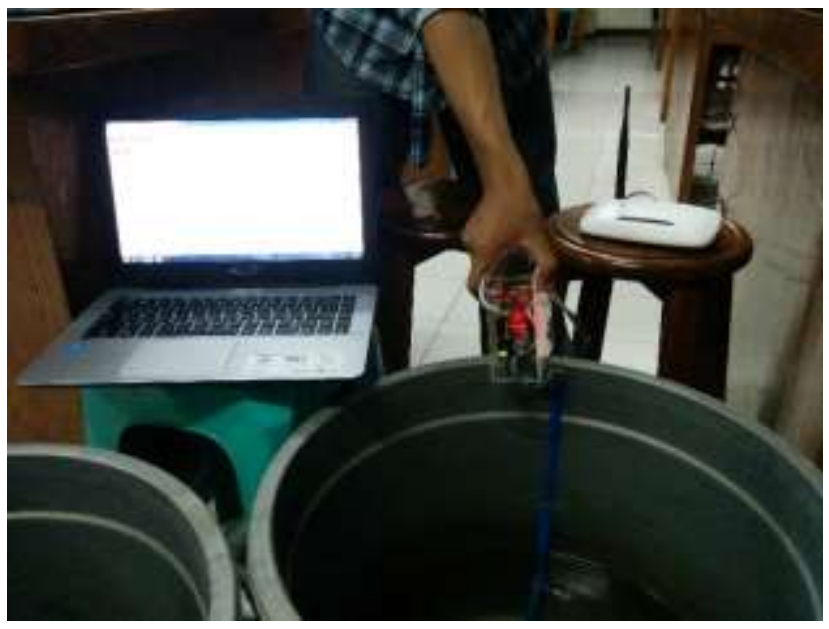

Gambar 5. Pengujian Keseluruhan 
Jurnal IImu Teknik Elektro Komputer dan Informatika (JITEKI)

Vol. 3, No. 2, Desember 2017

\section{Kesimpulan}

Dari hasil penelitian yang telah dilakukan didapat beberapa kesimpulan sebagai berikut :

1. Alat yang dibuat dapat untuk memantau ketinggian air pada bendungan serta peringatan untuk memantau tinggi permukaan.

2. Penggunaan sensor ultrasonik sudah bekerja sesuai dengan fungsi dan kegunaannya. Sensor ultrasonik dapat mendeteksi tinggi mata air pada bendungan.

3. Hasil dari pembacaan sensor ultrasonik akan ditampilkan pada web yang terdapat pada komputer secara kontinu.

4. Keseluruhan alat pada perangkat alat ukur tinggi mata air dapat bekerja dengan baik dan sudah bekerja seperti kegunaan dan fungsi dari sensor yang digunakan, karena dari hasil pengujian data yang ditampilkan sesuai dengan yang diharapkan.

\section{Referensi}

[1] Informasi Bencana Banjir, http://www.bnpb.go.id/berita/2782/jelang-puncak-hujantingkatkan-kewaspada diakses 28 Januari 2016.

[2] Widjaja, dkk. 2012. Pemantau Tinggi Air Otomatis Untuk Bendungan Katulampa. Universitas Bina Nusantara Jakarta.

[3] Rachmadi, Karlisa Priandana. 2014. Sistem Monitoring Ketinggian Air Melalui SMS Berbasis Mikrokontroler Arduino Uno. Institut Pertanian Bogor

[4] Fadlum. 2011. Alat Tinggi Muka Air Berbasis Sensor Ultrasonik. Universitas Ahmad Dahlan Yogyakarta 